\title{
INFLUENCING FACTORS IN TEACHING-LEARNING MATHEMATICS AMONG INDIGENOUS STUDENTS
}

\section{JAGAT KRISHNA POKHAREL}

Tribhuvan University, Kirtipur, Nepal

\begin{abstract}
Nepal is one of the smallest landlocked and developing countries, among developing nations in the world. It is full of environmental and geographical variations. Variations are extremely seen socially, economically and politically in a Nepali way of existence. The present study seeks to ascertain the impact of any social, economic environment of the place where students lived and studied in their achievement in mathematics.

Every research is important in itself because it unfolds various unseen facts in any area of study the study would found out if there is a variation in mathematics achievement among the students of rural and urban areas and rich and poor economic background. The achievement test paper was the main instrument adopted in this study. This study was limited 380 students selected from 15 schools (5 urban/10 rural areas) or through simple random sampling technique. This result of the study is based included in the sample.

KEYWORDS: Indigenous, Ethics \& Ethno mathematics
\end{abstract}

Received: Feb 16, 2018; Accepted: Mar 09, 2018; Published: Apr 09, 2018; Paper Id.: IJESRAPR201814

\section{INTRODUCTION}

Nepalese society requires the service of mathematics education for its continuity and for further development. Mathematics education is one of the essential parts of the whole education. Education is defined as a continuous and lifelong process. It is the process of development of inner potentiality of each individual from infancy to maturity. Education brings changes in human's behavior. The main functions of education are to remain more transmission of enrichment of culture. Education must provide every experience of all situations of life and reality within the maturity and ability of the individual to stimulate creativeness of mind which can explore new horizons and bring the vision of the future into a living reality.

Education should help every child in every community to become a useful and responsible member of the society for individual development as well as for the development of a country.

Education is the greatest force for building up a country economically, socially and culturally. The challenges have to be accepted by education's who are the real builders of the nation. Unless education in properly planned and organized, it is not possible for the social welfare of all.

By an Act no-20 of 2058 B. S., the National Committee was replaced by National Foundation for Development of Indigenous/Nationalities. A new updated list of Indigenous Nationalities was published in the schedule of (NFDIN) and terms were defined as:- 
"Indigenous/Nationalities people are those who have their mother languages and traditional customs, district cultural identities, distinct social structure and having written or non written history, the ethics or their community listed in the schedule." (NFDIN, 2001)

According to the Census (2001 AD), 37.19\% of the total population of Nepal is Indigenous/ Nationalities. There is a data record of 101 castes or ethnics where data of only 43 Indigenous/Nationalities were recorded. Magar community is the largest community among all Indigenous/Nationalities of Nepal, where it is also the third largest community of Nepal just after Chettri and Brahmin castes. Magar community covers 7.14\% of the total population of Nepal. Similarly, Tharu (6.75\%), Tamang (5.67\%), Newar (5.48\%), Rai (2.79\%), Gurung (2.39\%), and Limbu (1.58\%). There seven Indigenous/Nationalities ethnic Group-Itself covers $31.77 \%$ of the total population of Nepal and other remaining Indigenous/Nationalities covers only $5.42 \%$ of the total population of Nepal. In fact, nearly 70 percent of the population total belongs to just ten major groups.

According to the 2001 Census, the literacy rate of Nepal is 53.8 percent; the male and the female literacy rate is 65 percent and 42.5 percent respectively. No doubt, the literary rate of Nepal is improving gradually over the year. At the same time, the literacy rate as a whole differs.

According to the Census 2001, the highest literacy groups among the Indigenous/Nationalities are Thakali (75.66\%), Newaf (71.22\%), Yehlmo (70.70\%) and Dura (63.26\%), Limbu (59.79\%), Gurung (59.79\%), Rai (58.19\%), Magar (55.90\%), Tharu (47.12\%) and Tamang (45.09\%).

\section{LITERATURE REVIEW}

The modern sciences and technology of this $21^{\text {st }}$ century are based on mathematical knowledge. There is a great role of mathematics towards the development of our society. Every field and discipline is more or less related to the mathematics. So, mathematics is considered as an important subject, called the queen of all sciences. Our society requires the service of mathematics education for its continuity and for further development. Mathematics was created by human need. It is a science development by human beings throughout their various civilizations. The word 'Mathematics' has been derived from the ancient Greek word 'Manthancian' that means to learn, which indicates that mathematics is a separate discipline of learning and interpreting of human life. (Pandit, 2069)

Mathematics education in its early stage was only for a few people and the contents of mathematics were comparatively simple, as time passed, many interesting, amazing and surprising facts, theories and new knowledge from different new fields were included in the content of mathematics. Nowadays mathematics is involved in every moment of human life. Daily communication involves the frequent use of mathematical concepts. So, every person in this modern world should be at least mathematically literate, mathematics is very necessary for every kinds of society. But learning and teaching mathematical facts, knowledge, skills and theories are very difficult because mathematics itself is known as the hard and difficult subject. On the other hand, mathematics education is not independent of social, cultural, political and economic factors of the contemporary society. That means there are several factors, which affect mathematics learning process, mainly socio-cultural factors are most influencing factors in mathematics education. Moreover, the whole education process is affected by these factors. The organization system of education must meet the real situation of the community. It must be in accordance with the physical and social needs of the community. 
Mathematics issues concerning the particular ethnic group and their cultural activities are termed as Ethno mathematics, an international journalist of mathematics education; U, D'Ambrosio, who introduced this concept of Ethno mathematics for the first time, is known as father of Ethnomathematics. He said:

'A relation between anthropological, cultural, historical and mathematical is an important step towards the reorganization of different work of thinking which directly to different mathematical forms this is what we call Ethno mathematics.' (D'Ambrosio, 1987)

Several comparative studies on the achievement in mathematics under different variables are conducted by different researchers. There are many factors that affect the achievement of students in mathematics learning; such as gender difference, class size, teaching method, teaching materials, parents' income, parents, education and occupation, geographical factors, learning facilities, ethnicity of students, physical, mental condition of students, teachers training, their experience and qualification, socio-cultural and religion, background of students and their communities and so on.

Studies carried by CNAS (1999), titled 'Nepal ko Pichadiyaka Jati haruko Samajik- Arthik Addhyan' included field survey reports about the social economic status of Bhat, Bote, Dhimal, and Tharu of Tanahu \& Chitwan district, regarding them as backward communities of Nepal. It mentioned about their cultural history, traditional costume, occupation, skills, religion, and health \& education background. The studies concluded that the educational background of above-mentioned communities was not satisfactory. They found that the enrollment rate of children from these communities was very low. On the opposite, the dropout rate was noticed very high at primary level because of their traditional costumes and occupation. But in the last part of study, it is stated that the educational awareness among these groups was rising slowly and they were getting a positive attitude towards formal education.

In a study carried on by CERID in 1999 entitled "Assessment of learning achievement of lower secondary children, Kathmandu" concluded that there were so many factors attributing to student achievement such as Household, Teacher and school-related factors. They were observed and examined as major factors to explain their effect on the student's achievement during that study. The following factors were found having a significant impact on grade 8 students' achievement in mathematics (1) sex of the students \& (2) Language spoken at home.

The researchers found that the achievement of boys in mathematics for the grade eight students scored significantly higher than that of girls. Also, the result of the grade eight students showed that the mean achievement acquired by them in four core subjects are 34.29 in English, 28.87 in mathematics, 68.80 in Nepali and 29.62 in Science. Thus the students had performed poorly in science and mathematics when compared to the general pass mark of 32.

In another study entitled "Children's learning obstacles" by the CERID (2001), stated that the educational status of the disadvantaged children was very low. Only 30 percent of the children are enrolled in schools. Most of the children enrolled drop out before completion the primary level. There were various reasons found behind the situation, mainly ethnicity, Occupation, Economic status, Society and in temporary settlement affect their education. The study declared the Dalits as the most disadvantaged group economically, socially \& educationally.

\section{METHODOLOGY}

This section describes the design of the plans and procedure of the study, which are to be carried out to achieve the objectives of this study. The study can be considered a survey study of students of secondary schools. The variables in this study were achievements of students in mathematics and the caste/ethnic groups of students as defined 
above within different strata with respect to the school area (Rural/Urban) \& school type (Private/Public). Other variables were not taken into consideration. Thus, the mathematical achievement was considered as the dependent variable and the caste/ethnic groups were the independent variable of the study. If possible, other extraneous variables were controlled during the study.

The researcher decided to carry out this research concerning the mathematical achievement of students belonging to the Indigenous/Nationalities and comparison of their achievement to the mathematical achievement of students belonging to other caste groups of Chitwan district. Chitwan district is selected as the research area because it is a common living area of all caste/ethnic groups of Nepal. It is also in the center of the country.

\section{Analysis}

In this chapter, the data collected by the MAT are tabulated \& presented in several tabulation \& charts, which are statistically analyzed \& interpreted. In order to analyze and interpret the collected data, descriptive \& statistical devices were used. The Null-hypothesis that formulated by the researcher were tested using two-tailed Z-test for the large sample at 0.05 level of significance. This chapter is divided into server sub-divisions with suitable headings, tables \& charts to make the presentation more effective, more comprehensive analysis and for meaningful interpretation.

\section{Distribution of Mean and Standard Deviation}

The mean and standard deviations of the scores obtained by the sample students on MAT is tabulated below.

Table1: Destitution of Mean and Standard Deviation

\begin{tabular}{|c|l|l|l|l|l|l|l|l|c|}
\hline \multirow{2}{*}{ S. No } & \multirow{2}{*}{ Name of School } & School Type & School Area & \multicolumn{2}{|c|}{ Group-I } & \multicolumn{3}{|c|}{ Group-II } \\
\cline { 3 - 10 } & Public/Private & Rural/Urban & n & Mean & S. D & n & Mean & S. D \\
\hline 1 & Nava Pravat Ma. Vi. & Public & Rural & 8 & 17.13 & 4.82 & 8 & 21.50 & 5.83 \\
\hline 2 & Khairahani Ma. Vi. & Public & Rural & 8 & 18.00 & 4.28 & 8 & 21.13 & 4.22 \\
\hline 3 & Chitwan Ma. Vi. & Public & Urban & 8 & 18.63 & 2.00 & 8 & 22.13 & 3.04 \\
\hline 4 & Nepal Ma. Vi. & Public & Urban & 8 & 19.75 & 3.33 & 8 & 23.25 & 4.92 \\
\hline 5 & $\begin{array}{l}\text { Rosemary } \\
\text { Kid's Foundation }\end{array}$ & Private & Rural & 8 & 21.00 & 5.13 & 8 & 24.63 & 4.03 \\
\hline 6 & Kamal Devi Ma. Vi. & Private & Rural & 8 & 20.13 & 3.18 & 8 & 24.38 & 5.66 \\
\hline 7 & $\begin{array}{l}\text { Narayani Sec. } \\
\text { Boarding School }\end{array}$ & Private & Urban & 8 & 23.13 & 5.77 & 8 & 22.38 & 5.42 \\
\hline 8 & $\begin{array}{l}\text { Sky Rider } \\
\text { Sec. Eng. B. School }\end{array}$ & Private & Urban & 8 & 23.50 & 3.85 & 8 & 27.38 & 3.38 \\
\hline
\end{tabular}

The research question of this study was focused to find out the mathematical achievement level of Indigenous/Nationalities ethnic groups and literacy rate. But as per the researcher assumption, the caste minorities groups like Kami, Damai, Sarki etc. belonging to the Indigenous/Nationalities caste groups who are also educationally, economically \& socially disadvantaged group of Nepal. Their literacy rate is also very low.

To compare their mean achievement to that of non-Indigenous/Nationalities students, in order to find out the answer to the question, the researcher selected a sample of 128 students of concern caste/ethnic groups from eight secondary schools. Possible extraneous, variables like gender difference, age, maturation, intelligence, facilities, location, school types were controlled by using a stratified random sampling method and also by selecting equal no of boys/girls, equal no of private/public schools from Rural \& Urban areas. The data collection tool for the study was the Mathematical Achievement Test (MAT) that was constructed \& standardized by the researcher himself. The test was standardized 
through a pilot survey in 'Himalayan International Ideal School, Dhobighat' a Private Boarding School and in 'Shree Gorakhnath Ma. Vi., Kirtipur' a Public Secondary School. The content validity was established by constructing the items of the test on the basis of specification chart (see Appendix- B) and suggestion of the respected guide. The reliability was measured by using split-half reliability, rest method and found to be good enough; further, the MAT was modified \& standardized by Item Analysis to make the final Mathematics Achievement Test more reliable and valid. After then the researcher administered the final MAT to the sample students of eight sample schools the researcher analyzed the data using various statistics tools. The significance difference of the mean achievement of students belonging to Group-I and Group-II was compared by two-tailed Z-test at 0.05 level of significance and interpreted the findings with respect to the different conditions of the study. The summary of the findings based on the data analyses is as follows:

- The mean achievement of students in mathematics from Non-Indigenous/Nationalities are significantly different than that of students from the Indigenous/Nationalities in Secondary Level.

- The mean achievement of students in mathematics from indigenous/nationalities and NonIndigenous/Nationalities are significantly different at public secondary schools.

- The mean achievement of students in mathematics from indigenous/Nationalities and NonIndigenous/Nationalities are significantly different at the private secondary school.

- The mean achievement of students in mathematics from indigenous/Nationalities and NonIndigenous/Nationalities are significantly different at secondary schools in rural areas.

- The mean achievement of students in mathematics from Indigenous/Nationalities and NonIndigenous/Nationalities are significantly different at secondary schools in urban areas.

- The mean achievement of students in mathematics from Indigenous/Nationalities at the private secondary school is significantly different than that of public secondary Schools.

- The achievement of students in mathematics from Indigenous/Nationalities at Urban area secondary schools is significantly different than that of the rural area secondary school of Chitwan district.

- The mean achievement of girls students in mathematics from Non- Indigenous is significantly different than that of girls students from the Indigenous/Nationalities in secondary level.

\section{CONCLUSIONS}

On the basis of statistical analysis of the scores of sample students obtained on the MAT, the researcher listed his findings above. All the research hypotheses were statistically accepted. From the findings, the researcher has made a conclusion that the ethnicity affects significantly in the mathematics achievement at secondary level education. Students belonging to Indigenous/Nationalities of Nepal with respect to overall comparison have school type-wise comparison and region-wise comparison. The mathematical achievement of students belonging to the Indigenous/Nationalities group was found significantly better in a private secondary school as compared to public secondary schools of Chitwan district. Also, the mathematical achievement of students belonging to the Indigenous/Nationalities group was found significantly better in urban area school than the rural area school in Chitwan district. The researcher realized that most of the students belonging to the Indigenous/Nationalities facing various problems such as poor economic status, negative attitudes towards the formal education, socio-cultural traditional factors, low rate of enrollment and high rate of dropout in primary level, 
language problem \& lack of attractive and suitable learning experience in the curriculum, early marriage \& use of child labor in rural areas, lack of awareness about education, and lack of facilities, proper guidance and motivation in schooling period.

\section{REFERENCES}

1. CERID. (1999). 'Assessment of learning achievement of Lower Secondary children, Kathmandu.'

2. CERID. (2001). 'Children's learning obstacles.'

3. CNAS. (1999). 'Nepal ko kehi Pichadiyaka Jati haru ko Samajik- Arthik Addhayan' Encyclopedia of Religion and Ethnics Vol-6 and Vol-7.

4. D'Ambrosio, Ubi. "Reflections on Ethnomathematics." International Study Group cn Ethnomathematics Newsletter 3 (1) (September 1987). Journal of psychological researcher (1985) Vol 29, (p.61-63).

5. $\quad$ K. C., R. Kumari. (2001). 'A comparative study of Achievement in mathematics of primary level students' of Chhetri, Tharu and Kami castes in Surkhet District.' Master's thesis, FOE. TU.

6. Khatiwada, P. K. (1975), 'A study to compare the students Activity Ratio and their Achievement in third grade mathematics conducted by trained and Untrained Teachers in the schools in Town of Birgunj', Master Thesis FOE, TU. National Council of Teachers of Mathematics. (1987). 'Mathematics Teacher'. (pp. 362-363).

7. Patiphat Tittha \& Duanghathai Katwibun, Investigating the Access to Mathematics and Conceptual Understanding of 10th Grade Students in a Problem-Based Learning (PBL) Classroom International Journal of Educational Science and Research (IJESR), Volume 6, Issue 2, March - April 2016, pp. 147-154

8. Neupane, S. R. (1985). 'A Study of the Achievement of Eight grade students in mathematics in selected school of Kaski, Dristrict Ph. D.' Thesis FOE, TU.

9. Pandit, R. P. (2069). Teaching Mathematics, Kathmandu, Indira pandit. Population Censu. ( 2001). National Report, HMG of Nepal, National Planning Commission Secretariat, Central Bureau of Statistics. Population Monograph of Nepal. (2003). VolI \& II, HMG of Nepal National Planning Commission Secretariat, CBS.

10. Rao, and Latha, P, (1995) 'Achievement in mathematics', Discovery Publishing House, New Delhi.

11. Sah, B. L. (2000). 'A comparative study of achievement in mathematics of Lower Secondary Level students of different ethnic groups' Master's thesis, FOE. TU.

12. Sedai, N. (2001). 'A Comparative Study of Achievement of the Eight Grade Students in the Unit Statistics'. Master thesis F. O. E., $T U$.

13. Bairagi Patra \& Ashok Kumar Mohanty, Importance of English for Engineering Students: An Evaluation of the Prevalent Teaching-Learning System in the Indian Context, International Journal of English and Literature (IJEL), Volume 6, Issue 4, July-August 2016, pp. 21-34

14. Sharma, K. Devi. (2000). 'A comparative study of the achievements of students of grade IX in the topic of vector of secondary school mathematics curriculum' Master Thesis, FOE, TU.

15. NFDIN. (2001). 'The Indigenous Nationalities of Nepal'

16. Ukyab, T. \& S. Adhikari. The Nationalities of Nepal, Ministry of Local Development, National Committee for Development of Nationalities, Anamnagar, Kathmandu, Nepal. 